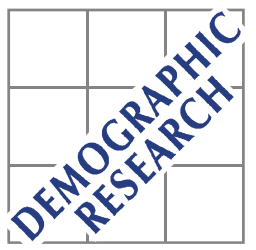

Demographic Research a free, expedited, online journal of peer-reviewed research and commentary in the population sciences published by the Max Planck Institute for Demographic Research Konrad-Zuse Str. 1, D-18057 Rostock · GERMANY www.demographic-research.org

DEMOGRAPHIC RESEARCH

VOLUME 8, ARTICLE 1, PAGES 1-30

PUBLISHED 9 January 2003

www.demographic-research.org/Volumes/Vol8/1/

DOI: 10.4054/DemRes.2003.8.1

Research Article

\title{
Who Marries Whom? \\ Educational Homogamy in Norway
}

Gunn Elisabeth Birkelund

Johan Heldal

(C) 2003 Max-Planck-Gesellschaft. 


\section{Table of Contents}

1 Introduction 2

2 Earlier research 2

3 Theoretical arguments 3

4 Data and variables $\quad 5$

4.1 Selection problems

4.2 Variables 6

5 Part I. Patterns of educational homogamy $\quad 7$

6 Part II. A marginal free measure of homogamy 10

6.1 The homogamy measure H. The general case 10

6.2 Model I, the saturated model 13

$\begin{array}{lll}6.3 & \text { Model II } & 14\end{array}$

6.4 Model III and IV 14

$\begin{array}{lll}7 & \text { Summary } & 16\end{array}$

$\begin{array}{lll}8 & \text { Acknowledgements } & 17\end{array}$

$\begin{array}{ll}\text { Notes } & 18\end{array}$

$\begin{array}{ll}\text { References } & 22\end{array}$

Appendix Tables 26 
Research Article

\title{
Who Marries Whom? Educational Homogamy in Norway
}

\author{
Gunn Elisabeth Birkelund 1 \\ Johan Heldal $^{2}$
}

\begin{abstract}
A number of previous studies have documented a fairly high level of marital homogamy in Norway. Most of these studies, however, have been local and ethnographic, or based on national data measuring homogamy within a limited time period.

This study is based on a sample of 129651 individuals from the 1980 Census. From this data bank, a sample of couples is constructed. Patterns of educational homogamy across five ten-year cohorts, born between 1900 and 1949, are compared. The results show a decline in educational homogamy across these cohorts, both in absolute terms and when controlling for the general increase in educational level during the period.
\end{abstract}

1 Department of Sociology and Human Geography, University of Oslo

2 Statistics Norway 


\section{Introduction}

Marital homogamy usually refers to marriage between partners of the same social group. Homogamy based on group affiliation may be - and indeed has been - defined in various ways; either by social background, by ethnic group, by religious group, by regional, demographic or social dispersion, by educational attainment, by status group or present social class. A high level of homogamy indicates few intimate and profound relations between members of different social groups. On the other hand, high rates of intermarriage are expected to reduce the ability of the family to pass on to its offspring group specific values and worldviews. Thus, intermarriage can be assumed to be a cause, as well as an indicator, of social and cultural openness and integration (McDowell 1971; Blau, Blum and Schwartz 1982; Labov and Jacobs 1986; Pagnini and Morgan 1990; Hout and Goldstein 1994; Botev 1994; Kalmijn 1991b, 1998; Smits, Ultee and Lammers 1998). (See note 1).

In this paper we will explore some elements of these features, focusing on educational homogamy in Norway, covering five cohorts, born between 1900 and 1949. Couples with similar level of education are defined as homogamous, whereas couples with different levels of education are not. (See note 2). The task we will investigate here is whether there in Norway are any trends across these cohorts in educational homogamy, and if so, what patterns can be detected.

The study is in two parts. In the first part, the propensity to homogamy is studied for married men and women separately. In the second part, a joint measure of homogamy is proposed, applied to couples. The data are considered differently in the two parts and selection biases affect the two parts differently, and this will be discussed. The study is conditional, given that marriage has taken place. The propensity to marry, which is an important part of the entire picture, has not been studied because of serious selection effects associated with such a study.

\section{Earlier research}

Previous Norwegian studies document a high level of homogamy, yet none of them explore trends over time in marriage patterns in Norway (Sundt [1866] 1992; Øyen 1964; Rogoff Ramsøy 1966; Dyrvik 1970; Birkelund 1987; Kravdal and Noack 1989; Blom, Noack and Østby 1993; Hansen 1995; Birkelund and Goodman 1997; Skrede 1999). (See note 3). Studies from other countries give a fairly differentiated picture of trends in homogamy over time: In some countries there has been an increase in homogamy, such as the USA (Mare 1991, Kalmijn 1991a) and Germany (Blossfeld and Timm 1997, referred in Kalmijn 1998). Other countries, however, show stability over 
time, and a Swedish study (see Henz and Jonsson 2000) shows a decline in educational homogamy over time. (See note 4).

Cross-national analyses have also shown a mixed pattern. In a study of 64 countries, (see note 5), educational homogamy is related to the level of economic development: "As the level of development increases, educational homogamy increases, subsequently peaks, and then decreases" (Smits, Ultee and Lammers 1998:281). In other words, this study found a non-linear relationship between the two variables 'educational homogamy' and 'economic development'. The study is based on a number (albeit large) of countries at different levels of 'economic development', not longitudinal data, which naturally limits the conclusions with regard to processes over time.

A common feature of most previous studies of marriage patterns has been their descriptive character, documenting patterns of homogamy within specific time and space constraints. As argued by Kalmijn (1998), there is less emphasis on the mechanisms that generate these patterns of marriage. Let us briefly consider theoretical arguments about marriage selection.

\section{Theoretical arguments}

Finding a partner for marriage is certainly related to "love" and sexual attraction. But attraction and "love" does not operate arbitrary; rather, marital selection is presumably related to seeking a partner with assets and qualifications, which are similar to one's own. Martial selection can therefore be understood in the same way as job selection, where individuals search for a partner in a marriage market rather than a job in a labour market (England and Farkas 1986).

At the individual level, two factors are important. First, marital selection is related to the preferences of individuals. Individuals are seen as agents who try to maximise (or satisfy) their future family income and social status by searching for what they regard as the most attractive partner. Since preferences reflect social and cultural values, the notion of attractiveness is expected to vary - not only among members of different social groups, but also over time. People with similar cultural backgrounds can be expected to share a "common universe of discourse" (DiMaggio and Mohr 1985) and are therefore likely to confirm each other's behaviour and worldviews (Kalmijn 1994). (See note 6).

Second, marital selection is related to and constrained by the opportunity structure, the marriage market. The structure of the marriage market influences the chances of individuals to realise their preferences. Marriage markets can be defined in terms of the overall demographic composition of the population as a whole, or in a more local fashion, such as educational institutions, workplaces, etc. (England and Farkas 1986; Mare 1991; Blossfeld, Timm and Dasko 1998, Dagsvik 2000). (See note 7). The 
marriage market consists of the population at risk of being chosen for marriage. Competition in the marriage market determines who gets whom. In a marriage market in equilibrium we would therefore expect that "The outcome of this competition is that the most attractive candidates select among themselves while the least attractive candidates have to rely on another" (Kalmijn 1998:398). At the societal level, competition for the most attractive partner (as measured by socio-economic resources) would lead to an aggregate pattern of homogamy. (See note 8).

In his study of the USA, Mare found evidence of increased homogamy between the 1930 s and the 1970s, which might be the result of "increasing competition in the marriage market for wives with good prospects in the labour market" (Mare 1991:15). This increase was, however, followed later by a decline in homogamy. (See note 9). This decline might be related to changes in the composition of the marriage market; for instance, a changing willingness to marry (increasing cohabitation) (Qian 1998), and/or a decreasing competition for women with good education, due to a greater supply of highly educated women in the younger cohorts.

Theoretical considerations and previous empirical research on the modernisation of the Norwegian society leads us to summarise our expectations:

1. It seems fair to argue that Norway at the beginning of the $20^{\text {th }}$ century was characterized by a gendered societal division of labour, where men's main responsibility was to be their family's breadwinner, and women's main responsibility was to take care of the household and children.

2. A majority of the first birth cohorts in the $20^{\text {th }}$ century would have no education above compulsory schooling. We would therefore expect a high level of educational homogamy in these cohorts; i.e. a majority of the married couples would consist of men and women with similar (the lowest) level of education.

3. Processes of modernisation implied, however, an increased demand for workers with education above compulsory schooling. Since boys were expected to be the breadwinners, more boys than girls were given opportunities by their parents for education beyond the level of compulsory schooling.

4. Thus, educational attainment increased more among men, than among women. The educational differences between men and women would lead us to expect a decline in educational homogamy over time; i.e. we would expect the older cohorts to be more homogamous than the younger cohorts.

5. Processes of further modernisation eventually implied new patterns of gender roles after WWII, leading more girls to take higher education as well. For cohorts born after WWII, we would therefore expect an increase in the association between the spouse's educational levels, in particular at higher levels of education. 


\section{Data and variables}

In order to explore our topic thoroughly we would need individual level data covering the marriage histories of individuals. This would require that actual marriages were related to the population at risk of marrying, men and women, at every point in time (Qian and Preston 1993). Then we would be able to analyse simultaneously whether people get married or not, who gets married, and to whom. We would also be able to explore first marriage, and - if divorce - whether people remarried, and if so, to whom (Blossfeld and Drobnič 2001). Unfortunately, we do not at present have these kinds of data. Rather, we will rely on a 10 percent sample of individuals from the 1980 census. For each person in this sample we have information about their marital status and level of education at the time of the census, and if married or once married, the same information on the spouse. Individuals who had never been married were excluded from the sample, as were individuals with missing information on their own educational level, or their partner's educational level. This made a sample of 129651 men and women. In part one of the study, where men and women are analysed separately, this sample is considered as two sub-samples of individuals, one for each gender. Individuals are classified into cohorts by their own birth year. In part two, the sample is considered as one sample of couples. The couples are classified into cohorts according to the average age of the spouses. Further details are given below.

\subsection{Selection problems}

There are selection problems related to our data that should be acknowledged. First, we might have a selection problem related to divorce. Kalmijn (1991a) pointed out that stability of inhomogamous couples is lower than stability of homogamous couples; thus, the degree of homogamy within cohorts will increase by time causing bias. However, we know that the oldest cohorts in our sample have low divorce rates. Statistics Norway documents that the cumulated divorce rates in 1980 are less than 10 percent for Norwegians who married between the 1920s, when the 1900-09 cohort was young, and the 1950s. (See note 10). People who married between 1955 and 1970 had the highest propensity of divorce, ranging from 11 to 14 percent. After 1970 divorce rates declined again. (See note 11). Men and women born in the 1930's and the 1940's are likely to have married between 1955 and 1970. Following Kalmijn, we might expect a selection favouring homogamous couples in these cohorts.

Second, and related to this, we may confound first and later marriages. For individuals who have been divorced or widowed and remarried we will not have 
information on their first marriage. We will thus not be able to explore, for instance, if couples that marry for the second time are more homogamous than first marriages.

Third, and without going into detail, due to relations between marital status, gender, education and mortality, the selection of survivors to 1980 will be biased samples of the original cohorts, in particular for the oldest ones. This can be expected to affect the unigender analysis in part one more than the analysis in part two, since univariate distributions for each gender in the first analysis can be biased without necessarily affecting log-linear association structures among variables or between genders seriously (the second analysis). However, selection bias can affect the analysis in part two if the propensity to homogamy was different for couples where no one survived until 1980 than for couples where at least one survived.

Fourth, we do not have information on cohabitation. This might affect the youngest cohorts in particular. The first so-called cohabiting cohort was born around 1950: Thirty percent of all Norwegians born between 1948 and 1952 started their first partnership as cohabitants; a figure that rose to 55 percent of those born between 1953 and 1957 (NOU 1999:262, Table 3.5). Thus, married couples within our 1950-59 cohort, which would be 21-30 years in 1980, would be a highly selected group. We will therefore not include this cohort in our analyses.

Finally, we have a problem related to duplicates. Approximately 10 percent of the women and 10 percent of the men in the original sample whose spouses were still alive will also have their spouse in the sample, thus generating duplicate couples. Among them, five percent of the sampled couples have another five percent as their duplicates. (See note 12). Since the proportion of couples where both are alive in 1980 is smaller in the older cohorts, these cohorts are less affected by the duplication. This duplication, which has taken place randomly but generates an overrepresentation of couples with two survivors, has not been accounted for in the analysis. (See note 13).

\subsection{Variables}

We have constructed a cohort variable, with five 10-year cohorts: The oldest cohort consists of individuals born between 1900 and 1909, and the youngest cohort comprises individuals born between 1940 and 1949. For women, each cohort is classified according to the women's year of birth. We do not include information about their husbands' age/cohort. Similarly, for men, each cohort is classified according to the men's year of birth. We do not include information about their wives' age/cohort. In part two of the analysis, where the units under study are couples, the ten year age cohort for each couple is based on the average year of birth for wife and husband. As 
mentioned above, the 1950-59 cohort will not be included in any part of our analyses. (See note 14).

Educational level is measured by the Norwegian Standard Classification of Education 1973 (Statistics Norway 1973), with a few modifications. (See note 15, Børke 1984:131 and Vassenden 1987:48):

Level 1: compulsory education (years 1-9, not including pre-school education) (grunnskole).

Level 2: secondary level I (10 years) (realskole/framhaldsskole/yrkesskole, etc.).

Level 3: secondary level II (11-12 years) (gymnas/vidergående skole).

Level 4: college/university level I (13-14 years).

Level 5: college/university level II (15-16 years).

Level 6: high university level (17 years or more).

For the spouses we only include the first five levels of education.

Marital status is a dichotomy, where individuals who are married at the time of the census, or who have been married before, are classified as married. Thus, those who are not and never have been married are classified as unmarried and excluded from our sample.

Let us now proceed by first addressing the educational attainment of men and women within each cohort.

\section{Part I. Patterns of educational homogamy}

Figure 1 shows the distribution of average educational attainment of each cohort, by sex. We see an increase in the average level of education from the oldest to the youngest cohorts, reflecting an overall rise in educational attainment. This development is well known in many countries (Shavit and Blossfeld 1993). We note that the gender gap in education is fairly stable across cohorts, except for the1950-59 cohort (i.e. individuals who were in their twenties in 1980), where women have gained in on men in terms of educational attainment.

Figure 2 shows educational homogamy by cohort, separately for men and women. Two categories of marriages have been distinguished: In homogamous marriages the spouses have the same level of education, in heterogamous marriages this is not the case. The heterogamous marriages may be characterised as 'marrying down' or 'marrying up' - depending upon one's point of view. A women with low education who has married a man with a higher education has 'married up', whereas her husband has 'married down'. This example is a fairly common pattern, reflecting different educational attainment of men and women. 


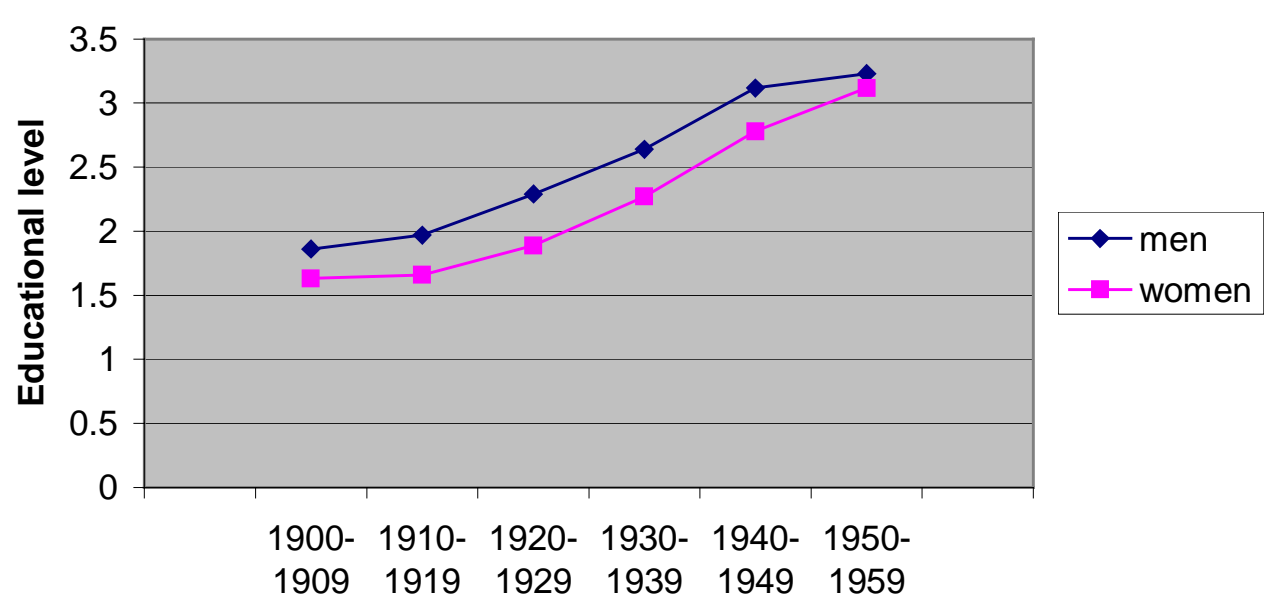

Figure 1: $\quad$ Educational level by cohort and gender

In the oldest cohort, approximately 70 percent of all marriages were homogamous, in the youngest cohort approximately 40 percent. In the oldest cohort, nearly all homogamous marriages consisted of couples where both partners had compulsory schooling as their highest educational level (see Tables A1 and A2 in Appendix). We also see that for both men and women, there is an increasing percentage across cohorts who 'marries up' - more often amongst women than men. There is also an increasing percentage across cohorts who 'marries down' - more often amongst men than women.

Thus, for Norwegians born in the first half of the $20^{\text {th }}$ century, who married at least once and survived to 1980, we find a decline across cohorts in the propensity to educational homogamy along with a general increase in educational attainment. One may question whether the observed trend is due to the changes in educational level alone or if there exists a component of the trend that cannot be attributed to these changes. 


\section{Homogamy by Birth Cohorts. Men. Percent.}

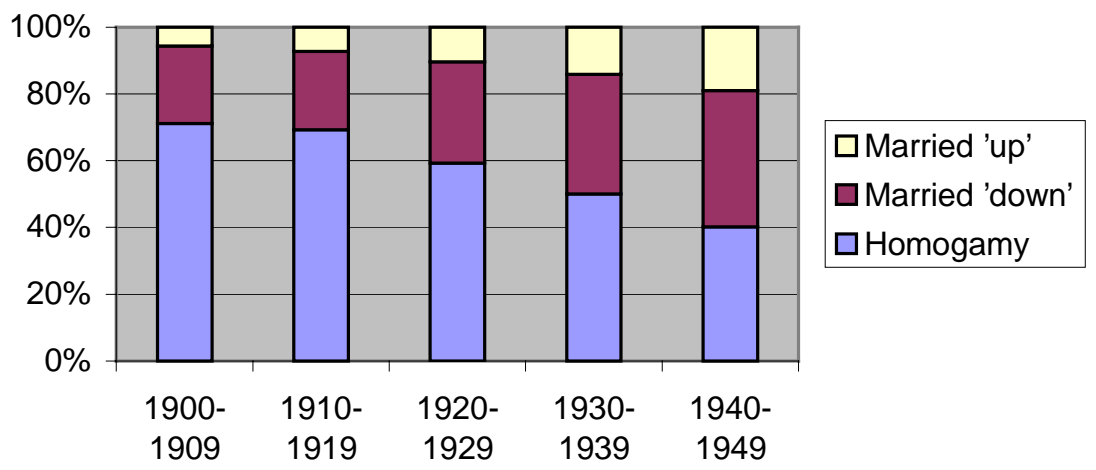

\section{Homogamy by Birth Cohorts. Women. Percent.}

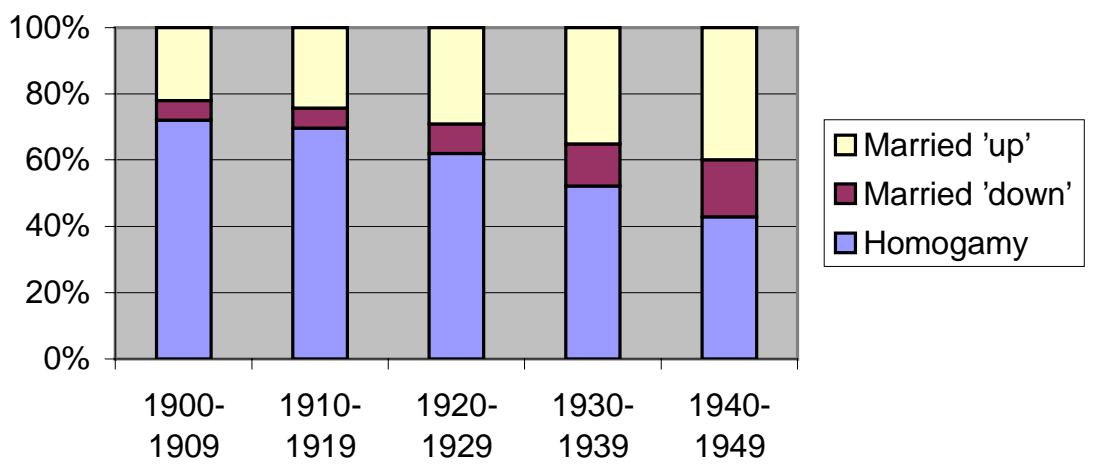

Figure 2: $\quad$ Educational homogamy 


\section{Part II. A marginal free measure of homogamy}

A generalised odds-ratio, called $H$, is constructed to measure the degree of homogamy. This special measure is constructed in such a way that it is unaffected by purely marginal changes in the distribution of men and women's educational level and is only sensitive to changes in the internal association structures in the $5 \times 5$ cross tabulations of both spouses' level of education. A value of $H$ larger than one indicates a general propensity to homogamy while a value less than one indicates the opposite. Changes in $H$ across cohorts therefore constitute changes in propensity to homogamy that are not due to changes in the distribution of level of education in the marginals of the $5 \times 5$ tables. The measure $H$ can be expressed and analysed in terms of the parameters of a log-linear model and can also be seen as a generalisation of the log-linear parameter that was used in Smits, Ultee and Lammers (1998) to describe the degree of educational homogamy in and across countries. When Smits et al study variation in educational homogamy across 65 countries with varying degree of technological and economical development, each at one point in time, we study educational homogamy across cohorts in one country. The main difference in the analysis is that the effect of the class variable "country", which is a purely nominal variable, has been replaced by "cohort", which is ordinal, and therefore sets the direction for a possible trend. As a generalised odds-ratio, $H$ and can be described by a set of contrasts for log linear parameters.

\subsection{The homogamy measure $H$. The general case}

Consider a $I \times I$ table for two categorical variables $X$ and $Y$, which in our application are her and his educational level in a randomly selected married couple. $X$ and $Y$ take values $x, y=1, \ldots, I=5$. The expected cell frequencies are $F_{x y}$. Consider the measure

$$
H=\frac{\left(\prod_{i=1}^{I} F_{i i}\right)^{1 / I}}{\left(\prod_{x \neq y=1}^{I} F_{x y}\right)^{1 / I(I-1)}}
$$

The nominator in (1) is the product of the expected cell frequencies for the diagonal cells and the denominator is the similar product for the off-diagonal cells. If $X$ and $Y$ are 
independent, $H=1$. A tendency to concentration on the diagonal makes $H>1$. It is easily seen that $H$ is not affected by multiplication of some row or column by a constant and therefore not affected by purely marginal changes of the table. Formulating the log expected cell frequencies in log-linear terms, that is

$$
\log F_{x y}=\lambda+\lambda_{x}^{X}+\lambda_{y}^{Y}+\lambda_{x y}^{X Y}
$$

$\log H$ is seen to be a contrast in the two-way parameters $\lambda_{x y}^{X Y}$ 's only:

$$
\log H=\frac{1}{I} \sum_{i=1}^{I} \lambda_{i i}^{X Y}-\frac{1}{I(I-1)} \sum_{x \neq y=1}^{I} \lambda_{x y}^{X Y}
$$

In $\log H$ each of the $I$ diagonal cells have been given a weight $1 / I$ while each of the $I(I-$ 1)off-diagonal cells have been given a weight $-1 / I(I-1)$. So the weights sum to zero across row and across each column and thus across all cells in the table. This is essential for making $\log H$ dependent of the $\lambda_{x y}^{X Y}$ 's only and independent of the row and column marginals.

Studying the variation of $H$ or $\log H$ over time or cohorts is equivalent to studying this quantity in each layer of a three-way table $F_{x y c}$ where the $c$ dimension represents the cohort variable $C$. The log-linear representation of such a three-way table is

$$
\log F_{x y c}=\lambda+\lambda_{x}^{X}+\lambda_{y}^{Y}+\lambda_{c}^{C}+\lambda_{x y}^{X Y}+\lambda_{x c}^{X C}+\lambda_{y c}^{Y C}+\lambda_{x y c}^{X Y C} .
$$

An interpretation of the third order parameters $\lambda_{x y c}^{X Y C}$ is as the effect of cohort category $c$ on the log-odds ratio for the husband's and the wife's education levels. (See note 16). In log-linear terms the $\log H$ for cohort $c$ can be expressed as

$$
\log H_{c}=\frac{1}{I} \sum_{i=1}^{I}\left(\lambda_{i i}^{X Y}+\lambda_{i i c}^{X Y C}\right)-\frac{1}{I(I-1)} \sum_{x \neq y=1}^{I}\left(\lambda_{x y}^{X Y}+\lambda_{x y c}^{X Y C}\right)
$$


$c=1, \ldots, C$. The difference for one cohort to the next can be formulated as

$$
\log H_{c}-\log H_{c-1}=\frac{1}{I} \sum_{i=1}^{I}\left(\lambda_{i i c}^{X Y C}-\lambda_{i i, c-1}^{X Y C}\right)-\frac{1}{I(I-1)} \sum_{x \neq y=1}^{I}\left(\lambda_{x y c}^{X Y C}-\lambda_{x y, c-1}^{X Y C}\right)
$$

The hypothesis of no change in the over all propensity of homogamy, that is the hypothesis

$$
\text { Hyp }_{0}: H_{0}=H_{1}=\cdots=H_{C}
$$

can be expressed as the hypothesis that the $C$ contrasts in the $\log H_{c}$ 's are zero:

$$
\log H_{c}-\log H_{0}=0, c=1, \ldots, C,
$$

or equivalently

$$
\frac{1}{I} \sum_{i=1}^{I}\left(\lambda_{i i c}^{X Y C}-\lambda_{i i 0}^{X Y C}\right)-\frac{1}{I(I-1)} \sum_{x \neq y=1}^{I}\left(\lambda_{x y c}^{X Y C}-\lambda_{x y c}^{X Y C}\right)=0,
$$

$c=1, \ldots, C$. This clearly only depends on the third-order effects. Particularly, if the homogeneity model indicating constant odds-ratios across layers hold, (all $\lambda_{x y c}^{X Y C}=0$ ), the hypothesis $H_{0}$ will also hold.

Six log-linear models were run. Table 1 tells how these models fit the data. In estimations with a large number of observations parameters may be deemed statistically significant from zero by the classical chi-square tests even when their deviations from zero are completely unsubstantial. An attempt to account for this is the $B I C$ measure, calculated by $G^{2}-d f \cdot \log n$, where $n$ is the number of observations in the table, here 128928. The $B I C$ criterion for choosing a model implies choosing the model with the lowest $B I C$.

By classical testing criteria, only model III, which defines a linear trend in the association between husbands and wives' education, fits the data. The BIC criterion prefers model VI, saying that this linear trend is symmetric in men and women's education level. 
Table 1: $\quad$ Seven models for the association between husband and wife's education across cohorts.

\begin{tabular}{lllll}
\hline Model & Description & $G^{2}$ & $d f$ & BIC \\
\hline I & Saturated model & 0 & 0 & 0 \\
II & Model I, but $\lambda_{x y c}^{X Y C}=\lambda_{y x c}^{X Y C}$ & 54.54 & 24 & -227.86 \\
III & Model I, but $\lambda_{x y c}^{X Y C}=\beta_{x y} \cdot c$ & 54.04 & 48 & $-510,78$ \\
IV & Model III, but $\beta_{y x}=\beta_{x y}$ & 91.85 & 54 & -543.57 \\
V & Model IV, but also $\lambda_{y x}^{X Y}=\lambda_{x y}^{X Y}$ & 341.76 & 60 & -364.26 \\
VI & $\lambda_{x y c}^{X Y C}=0$, Homogeneity model & 845.11 & 64 & 92.02 \\
\hline
\end{tabular}

\subsection{Model I, the saturated model}

Table 2 shows the estimates $\hat{H}_{c}, c=0, \ldots, 4$ for the five cohorts and $\log$ of the ratio of $H_{c}$ to $H_{0}$, which measures the change compared to the reference cohort 1900-1909. The estimates, which are based on the fits from a saturated model, indicate a decline in $H$ over cohorts.

Table 2: $\quad$ Estimates of the homogamy measure $H$ for five cohorts based on the saturated model (model I), relative change and 95\% confidence bounds for the relative change.

\begin{tabular}{llllll}
\hline Cohort & $c$ & $H_{c}$ & $H_{c} / H_{0}$ & Lower bound & Upper bound \\
\hline $1900-09$ & 0 & 3.081 & 1 & & \\
$1910-19$ & 1 & 3.079 & 0.9994 & 0.8139 & 1.2272 \\
$1920-29$ & 2 & 2.762 & 0.8964 & 0.7377 & 1.0892 \\
$1930-39$ & 3 & 2.732 & 0.8867 & 0.7316 & 1.0747 \\
$1940-49$ & 4 & 2.631 & 0.8539 & 0.7068 & 1.0317 \\
\hline
\end{tabular}




\subsection{Model II}

Model 3 and 4 by Smits et al (1998) was essentially similar to our model II except that $\lambda_{x y c}^{X Y Z}$ was given further structure of the form

$$
\lambda_{x y c}^{X Y Z}=\gamma_{c} S(x, y),
$$

where $S(x, y)$ was taken to be $|x-y|^{\alpha}$ (symmetric) and $\alpha$ was taken as 1 and 1.5 in the two models. In particular, $S(x, x)=0$. In their model $c$ represented country, not cohort, and it could therefore not define a trend. Model II says that the inhomogeneity of the odds ratios between $X$ and $Y$ (with the homogamity cells $x=y$ as references) across cohorts increases symmetrically with difference in education level between the two spouses. This symmetric structure is the same for all cohorts but its size is modulated for the different cohorts with the parameter $\gamma_{c}$. However, this model does not fit our data. (See note 17).

\subsection{Model III and IV}

Model III says that for each combination of husbands and wives' education level, there is a linear trend over cohorts in the log-odds ratios for each specific combination of husband's and wife's education level. The log-linear formulation of the model is

$$
\lambda_{x y c}^{X Y C}=\beta_{x y} c, c=0,1,2,3,4 .
$$

In our data this model has 48 degrees of freedom.

The estimates of the trend parameters are given in table 3. Model III therefore implies a linear trend in the generalised log odds for homogamy, $\log H_{c}=\log H_{0}+c \log \left(H_{1} / H_{0}\right)$, or $H_{c}=H_{0}\left(H_{1} / H_{0}\right)^{c}$. The estimate of $\log \left(H_{1} / H_{0}\right)$ is completely determined by the estimates in table 3 and is computed as the average of the betas on the diagonal minus the average of the betas off the diagonal (see appendix). The resulting estimates are $\log \hat{H}_{0}=1.117$ and $\log \left(\hat{H}_{1} / \hat{H}_{0}\right)=-0.0379$. 
Table 3: $\quad$ Trends $\beta_{x y}$. X her education level, $Y=$ his educational level. Model III.

\begin{tabular}{cccccc}
\hline$X \backslash Y$ & 1 & 2 & 3 & 4 & 5 \\
\hline 1 & -0.2321 & 0.0043 & 0.0845 & 0.0716 & 0 \\
2 & 0.2034 & 0.1306 & 0.1850 & 0.1497 & 0 \\
3 & 0.0884 & 0.1491 & 0.1700 & 0.1486 & 0 \\
4 & -0.1061 & -0.1039 & -0.0468 & -0.0511 & 0 \\
5 & 0 & 0 & 0 & 0 & 0 \\
\hline
\end{tabular}

The number 0.1850 in cell $(2,3)$ in Table 3 can be interpreted by saying that the odds that a man with education level 3 finds a spouse with education level 2 rather than one with education level 5 (reference category) compared to the same odds for a man with education level 5, has, in average, been increasing with the factor $e^{0.1850}=1.203$ each decade through the first five decades of the twentieth century. The numbers in the other cells can be interpreted similarly. This estimate is significantly different from zero with a $p$-value of 0.0006. It should be noted that none of the negative numbers in row 4 of table 3 are individually significantly different from zero. The dominating contribution to this result is the reduction in propensity of men and women in the lowest educational category to find a spouse in the same category expressed by the negative number 0.2321 in cell $(1,1)$. Table 4 is the equivalent of table 2 for model III.

Table 4: $\quad$ Estimates of the homogamy measure $H$ for five cohorts based on model III, relative change and $95 \%$ confidence bounds for the relative change.

\begin{tabular}{llcccc}
\hline Cohort & $k$ & $H_{k}$ & $H_{k} / H_{0}$ & Lower bound & Upper bound \\
\hline $1900-09$ & 0 & 3.056 & 1 & & \\
$1910-19$ & 1 & 2.943 & 0.9628 & 0.9422 & 0.9838 \\
$1920-29$ & 2 & 2.833 & 0.9270 & 0.8877 & 0.9679 \\
$1930-39$ & 3 & 2.728 & 0.8925 & 0.8364 & 0.9523 \\
$1940-49$ & 4 & 2.626 & 0.8592 & 0.7881 & 0.9369 \\
\hline
\end{tabular}

The corresponding change in the generalised log odds-ratio per decade is

$$
\log H_{c}-\log H_{c-1}=\frac{1}{I} \sum_{i=1}^{I} \beta_{i i}-\frac{1}{I(I-1)} \sum_{x \neq y=1}^{I} \beta_{x y}=-0.0379, k=1, \ldots, K
$$


Model IV is similar to model III except that the symmetry of the beta matrix is claimed: $\beta_{x y}=\beta_{y x}$. This can be called a symmetric trend model. The model provides the estimates $\log \hat{H}_{0}=1.112$ and $\log \left(\hat{H}_{1} / \hat{H}_{0}\right)=-0.0362$. The estimates for the beta matrix are given in Table 5 .

Table 5: $\quad$ Trends $\beta_{x y} . X=$ her education level, $Y=$ his educ. level. Model IV

\begin{tabular}{ccllll}
\hline$X \backslash Y$ & 1 & 2 & 3 & 4 & 5 \\
\hline 1 & -0.2473 & 0.1615 & 0.1144 & -0.0550 & 0 \\
2 & 0.1615 & 0.2676 & 0.2352 & 0.0330 & 0 \\
3 & 0.1144 & 0.2352 & 0.2043 & 0.0200 & 0 \\
4 & -0.0550 & 0.0330 & -0.0200 & -0.1512 & 0 \\
5 & 0 & 0 & 0 & 0 & 0 \\
\hline
\end{tabular}

For each cohort the propensity to marry homogamously has declined. Thus, our hypothesis about a decline in educational homogamy is empirically supported, also after we have controlled for the increasing education attainment across these cohorts.

One could think of a modification of the measure $H$ to weight the off diagonal cells differently with weights $v_{0} \geq v_{1} \geq \cdots \geq v_{I-2} \geq v_{I-1}$ (with at least one strict inequality) depending of how far the cell is from the diagonal. Such a measure would present a more detailed model of homogamy, yet it would not be completely independent of the marginals in the two-way table. Since our main purpose has been to validate our finding about decreasing homogamy across these cohorts considered, we will not consider other models of association here.

\section{Summary}

Both in absolute and relative terms there has been a decline in educational homogamy in Norway for cohorts born between 1900 and 1949. As we expected, educational homogamy is strongest in the oldest cohorts, reflecting the fact that very few people born at the beginning of the $20^{\text {th }}$ century had more than compulsory schooling. As Norway industrialized, the propensity to marry homogamously gradually declined, reflecting the wider dispersion of education within the cohorts born in the 1920s, 1930s and 1940s. In particular, amongst the heterogamous marriages, men were more likely to marry 'downwards' than opposite, reflecting men's likelihood of having equal or higher educational attainment than women. This trend complies with anticipations from 
theoretical considerations pointing at the separation of breadwinning and care taking work in the families due to the industrialisation of the society and the increasing demands for education of men (as breadwinners) compared to women (as caretakers). Our results show that this decline in educational homogamy is sustained even after we control for the overall increase in educational attainment across these cohorts.

We have focused on cohorts born in the first half of the $20^{\text {th }}$ century. The changes that took place within the cohorts born in the 1950s and later have not been investigated in this article. It might be the case that as more women undertake higher education, more men with high education will find a spouse at a similar educational level, resulting in an increase in high-level educational homogamy. This question will be addressed later with data from the Census 2001.

\section{Acknowledgements}

An earlier version of this paper was presented at a conference of the International Sociological Association's Research committee 28 on Social Stratification and Mobility, Libourne, France 10-14 May 2000; and at the Frisch-seminar, Stavern, Norway, 5-6 June 2000. We also wish to thank the anonymous referees of Demographic Research for valuable comments. The data applied in this publication are based on a 10 percent sample of The Norwegian Census Data Bank 1980. This data set has been made available by The Norwegian Social Science Data Service (NSD). Neither Statistics Norway nor NSD are responsible for the analyses/interpretation of data presented here. 


\section{Notes}

1. Studies of marital homogamy, and its counterpart intermarriage, also give insight into social inequality and differentiation. Since income and other resources are related to the household, marital homogamy could imply larger inequalities between households than between individuals.

2. Given that many women, in particular in the oldest cohorts, have not been gainfully employed, education is a more convenient measure of homogamy than for instance occupationally based class or stratification schemes.

3. Homogamy is defined in different ways in these studies, e.g. social class, regional affiliation, education. For an overview of Norwegian family sociology, see Eriksen and Wetlesen 1996.

4. A common feature in the (Western) societies analysed "has been a decline in the importance of social background for marriage choice", indicating that in younger cohorts, parents have less control over their children's choices, as well as the increasing importance of new marriage markets, such as the schools and universities (Kalmijn 1998:411).

5. Including a Norwegian survey from 1972.

6. This is the case, not only for individuals from different social origins, but also for gender: The traditional gender division of labour implies gender specific roles: A male provider and a female caretaker. Based on these family values, for women, an attractive man will be expected to be a good family provider, whereas for men, an attractive woman will be expected to be a good mother and housewife. Partner's educational attainment will therefore be more important for women than for men. More modern values, not based on a traditional gender role system, would imply, at least partly, different sets of preferences. Today, women take longer education and also participate in the labour market. Thus, educational attainment is important to women as well as men. When women take more part in the labour market, their human capital is more important, also for the men who marry them. In a similar vein: When men take more part in care work at home, their potential as a good father is also of importance for the women who marry them. Therefore, women would be expected to prefer men who could both be a good provider and a good father. (See Wærness 1987; Thagaard 1997; Ellingsæter 1998; Crompton 1999). Value systems, such as modern gender values, are also differentiated across social groups, such as generations and social classes. 
7. Institutions of higher education are important both as marriage markets and as institutions that might affect the students' preferences. Workplaces are important, for the same reasons, etc.

8. This argument does, however, ignore the possibility of market constraints, such as shortages of a particular type of potential partners. Oppenheimer (1988) have argued that women might search for a longer time period after a marital partner if there are shortages of men with attractive qualifications. This can imply, for instance, that women with high education delay or drop marriage. If this were the case, we would not expect an aggregate pattern of homogamy, at least not at the highest levels of education (i.e. women with high education would be less likely to marry). However, in a situation of shortage of potential 'suitable' partners, women might choose another strategy: They might expand their 'pool' of potential partners by lowering their preferences, i.e.: "cast a wider net". If this were the case, we would expect a higher ratio of heterogamous marriages. Lichter et al. (1995:412) did not, however, find support of this thesis; rather, they found that "market conditions - good or bad - have little to do with women's willingness to marry heterogamous". Their research thus indicate that the supply of potential mates (i.e. the population at risk) does not have any bearing on the patterns of associative mating: "we found little evidence that mate surpluses or deficits in the local marriage market affect patterns of homogamy or associative mating." (Lichter et al., 1995:412). Thus, whereas the market situation (population at risk) seems to have a bearing on women's willingness to marry (Qian and Preston 1993, Lichter et al. 1995, Lewis and Oppenheimer 2000), it appears to be less vital for studies of marital homogamy.

9. Mare (1991) has also shown that the timing of the transition out of school and into marriage is important. See also Chan and Brendan (2000).

10. Of all couples that married in 1920, 5,82 percent were divorced in 1980; of all couples that married in 1926, 7.02 percent were divorced in 1980, etc. up to 9,99 percent of all couples that married in 1954 (T. Noack, Statistics Norway).

11. These cumulated divorce rates are calculated on the basis of the actual marriage cohorts within each year independent of other reasons for marriage break-up, such as death.

12. The sample was a 10 percent sample of individuals from the census with spouses or former spouses linked. Among them $\mathrm{N}$ men and the same number of women had (former) spouses still alive at the time of the 1980 census. Each person is sampled with probability $\mathrm{p}=0,1$. Considering the sampling as a sampling of couples we can for each of the $\mathrm{N}$ couples have four possible outcomes: 
1. "Neither of the spouses is drawn." This has probability $(1-p)^{2}=0.81$

2. "Husband is drawn but not the wife" has probability $p(1-p)=0.09$ giving rise to $0.09 \mathrm{~N}$ couples in the sample.

3. "Wife is drawn but not the husband" has probability $\mathrm{p}(1-\mathrm{p})=0.09$ giving rise to $0.09 \mathrm{~N}$ couples in the sample.

4. "Both are drawn" has probability $\mathrm{p}^{2}=0.01$ giving rise to $0.01 \mathrm{~N}$ couples represented twice in the sample.

Thus, among the $\mathrm{N}$ couples $0.09 \mathrm{~N}+0,09 \mathrm{~N}+2 \cdot 0.01 \mathrm{~N}=0.20 \mathrm{~N}$ couples are represented in the sample, of whom $0.01 \mathrm{~N}$, or 5 percent, have copies.

13. The average age difference between the spouses included in these analyses differs to a certain extent. The oldest cohort (1900-1909) has on average 2 years age difference between the spouses, whereas spouses in the next cohort (1910-1919) differ with 0.8 years. The other cohorts reveal an age difference between the spouses close to 0 . We do therefore, not regard this selection as a large problem for the interpretation of our finding, yet, caution is advisable.

14. 57 percent of the men and 36 percent of the women in this cohort were unmarried. This is to be expected, since this cohort was 21-30 years at the time of the 1980 census, and many individuals in this cohort have not yet had time to marry.

15. The changes are related to old types of education (undertaken before 1973) which was not classified in 1973; education that was classified with other types of education in 1973, but later given a separate code; education that did not exist in 1973, but did so in 1980, and finally, education undertaken abroad. (Vassenden 1987:48).

16. The $\lambda$ 's are not uniquely defined unless further specifications are given. This however, does not affect the measure $H$. In the analyses of model I, III and IV the specifications used are $\lambda_{x y c}^{X Y C}=0$ when $x=5$ or $y=5$ or $c=0$ which are reference categories for the three variables involved. This gives $\lambda_{x y c}^{X Y C}$ the interpretation as the difference (or inhomogeneity) in the log-odds ratio of education level $(x, y)$ versus $(5,5)$ for cohort $c$ versus cohort 0 . In the analysis of model II it has been more convenient to choose the diagonal cells where $x=y$ as references.

17. A trend model of this kind would be the same as taking model IV with $\beta_{x y}=\beta_{y x}=\gamma|x-y|^{\alpha} . \quad$ Set $\quad \bar{S}=\sum_{x \neq y=1}^{I} S(x, y) / I(I-1)=\sum_{x \neq y=1}^{I}|x-y|^{\alpha} / I(I-1)$, 
the average of $S(x, y)$ over all off-diagonal cells. Then by (2), $\log H_{c}-\log H_{c-1}=\left(\gamma_{c}-\gamma_{c-1}\right) \bar{S}$, meaning that in the particular models of Smits et al. variations in $\log H_{c}$ and variations in $\gamma_{c}$ across cohorts or countries are equivalent expressions of the same variations. Though, $H_{c}$ is more generally defined and applies to a larger class of models. 


\section{References}

Birkelund, Gunn Elisabeth (1987) "Familien i klassesamfunnet." In Tom Colbjornsen, Gunn E. Birkelund, Gudmund Hernes and Knud Knudsen: Klassesamfunnet på hell. Bergen/Oslo: Universitetsforlaget.

Birkelund, Gunn Elisabeth and Leo. A. Goodman (1997) “"Birds of a feather flock together'. The Association between Husband's and Wife's Occupations in Norwegian Two-Earner Families". In Sigmund Grønmo and Bjørn Henrichsen (eds.): Society, University, and World Community. Essays for Ørjar Øyen. Oslo: Scandinavian University Press. Pp.136-151.

Blau, Peter, Terry C. Blum and Joseph E. Schwartz (1982) "Heterogenicity and Intermarriage." American Sociological Review, 47: 45-61.

Blom, Svein, Turid Noack and Lars Østby (1993) Giftemål og barn - bedre sent enn aldri? Samfunnsøkonomiske studier 81; Statistics Norway.

Blossfeld, Hans-Peter, Andreas Timm and Faith Dasko (1998) The Educational System as a Marriage Market. A Longitudinal Analysis of Marriage in the Life Course. Working Paper no. 46, Sonderforschungsbereich 186, University of Bremen.

Blossfeld, Hans-Peter and Sonja Drobnič (eds.) (2001) Careers of Couples in Contemporary Societies. From Male Breadwinner to Dual Earner Families. Oxford University Press.

Botev, Nicolai (1994) "Ethnic Intermarriage in the Former Yogoslavia, 1962 to 1989." American Sociological Review, 59: 461-80.

Børke, Sindre (1984) Folke- og boligtelling 1980. Dokumentasjon. Rapport 84/15, Oslo-Kongsvinger: Statistisk sentralbyrå.

Chan, Tak Wing and Brendan Halpin (2000) Who Married Whom in Great Britain? Essex: ISER Working Papers no 2000-12.

Crompton, Rosemary (ed.) (1999) Restructuring Gender Relations and Employment. The Decline of the Male Breadwinner. Oxford: Oxford University Press.

DiMaggio Paul and John Mohr (1985) "Cultural Capital, Educational Attainment and Marital Selection”, American Journal of Sociology, 90:12231-61.

Dagsvik, John K. (2000) “Aggregation in Matching Markets”, International Economic Review, 41:27-57. 
Dyrvik, Ståle (1970) "Om giftarmål og sosiale normer. Ein studie av Etne 1715-1801", Tidsskrift for samfunnsforskning, 11:285-300.

Ellingsæter, Anne Lise (1998) "Dual Breadwinner Societies: Provider Models in the Scandinavian Welfare States". Acta Sociologica, 41:59-73.

England, Paula and George Farkas (1986) Households, Employment and Gender: A Social, Economic and Demographic View. New York: Aldine Publications.

Eriksen, John and Tone Schou Wetlesen (1996) "Family Theory and Research in Norway: A Review Essay of the 1980s". Marriage and Family Review, vol. 23: 681-721.

Hansen, Marianne Nordli (1995) Class and Inequality in Norway. Oslo: Institute for Social Research.

Henz, Ursula and Jan O. Jonsson (2000) "Who Marries Whom in Sweden? Educational Homogamy in Historical and Longitudinal Perspective". Paper presented at the meeting of the ISA Research Committee on Social Stratification in Libourne, France, May 11-14 2000.

Hout, Michael and Joshua R. Goldstein (1994) "How 4.5 Million Irish Immigrants became 40 Million Irish Americans: Demographic and Subjective Aspects of the Ethnic Composition of White Americans". American Sociological Review, 59:64-82.

Kalmijn, Matthijs (1991a) "Staus Homogamy in the United States", American Journal of Sociology, 97:496-523.

Kalmijn, Matthijs (1991b) "Shifting Boundaries: Trends in Religious and Educational Homogamy”, American Sociological Review, 56:786-800.

Kalmijn, Matthijs (1994) "Assortative Mating by Cultural and Economic Occupational Status", American Journal of Sociology, 100:422-52.

Kalmijn, Matthijs (1998) "Intermarriage and Homogamy: Causes, Patterns and Trends" Annual Review of Sociology, 24:395-421.

Kravdal, Øystein and Turid Noack (1989) "Like Marriages Like - the Safest Choice? A Brief Study of Homogamy and Heterogamy in Norwegian Marriages", Scandinavian Population Studies, 9:243-258.

Labov, Teresa and Jerry A. Jacobs (1986) “Intermarriage in Hawaii. 1950-83”, Journal of Marriage and the Family, 48: 79-88. 
Lewis, Susan K. and Valerie K. Oppenheimer (2000) "Educational Assortative Mating Across Marriage Markets: Non-Hispanic Whites in the United States", Demography, 37: 29-40.

Lichter, Daniel T., Robert N. Anderson and Mark D. Hayward (1995) „Marriage Markets and Marital Choice“, Journal of Family Issues, 16: 412-431.

Lieberson, Stanley and Mary C. Walters (1986) From Many Stands: Ethnic and Racial Groups in Contemporary America. New York: Russel Sage Foundation.

Mare, Robert (1991): "Five Decades of Educational Assortative Mating", American Sociological Review, 56:15-32.

McDowell, Sophia F. (1971) "Black-White Intermarriage in the United States", International Journal of Sociology of the Family, 1 (special issue): 49-58.

NOU (1999) Samboere og samfunnet. Statistics Norway.

Oppenheimer, Valerie K. (1988) "A Theory of Marriage Timing", American Journal of Sociology, 94: 563-591.

Pagnini, Deanna L. and S. Philip Morgan (1990) "Intermarriage and Social Distance among U.S. Immigrants at the Turn of the Century", American Journal of Sociology, 96:405-32.

Qian, Zhenchao (1998) "Changes in Assortative Mating: The Impact of Age and Education, 1970-1990", Demography, 35: 279-292.

Qian, Zhenchao and Samuel H. Preston (1993) "Changes in American Marriage, 1972 to 1987: Availability and Forces of Attraction by Age and Education." American Sociological Review, 58:482-495.

Ramsøy, Natalie Rogoff (1966) "Assortative Mating and the Structure of Cities", American Sociological Review, 31:773-86.

Shavit, Yossi and Hans-Peter Blossfeld (eds.) (1993) Persistent Inequality. Changing Educational Attainment in Thirteen Countries. Boulder, Colorado: Westview Press.

Skrede, Kari (1999) “Drømmen, dyden og belønningen.” In Birkelund, Gunn Elisabeth, Anne Kathrine Broch Due and Ann Nilsen (eds.): Ansvar og protest. Kjønn, klasse og utdanning i senmoderniteten. Festschrift for Hildur Ve. Department of Sociology, University of Bergen. 
Smits, Jeroen, Wout Utlee and Jan Lammers (1998) "Educational Homogamy in 65 Coutries: the explanation of Differences in Openness with Country-level Explanatory Variables", American Sociological Review, 63:264-285.

Statistisk Sentralbyrå (1973) Standard for utdanningsgruppering. (Norwegian Standard Classification of Education). Oslo: Statistisk Sentralbyrås Håndbøker 28/73.

Sundt, Eilert ([1866] 1980) On Marriage in Norway. Cambridge : Cambridge University Press.

Thagaard, Tove (1997) "Gender, Power, and Love: A Study of Interaction between Spouses". Acta Sociologica, 40:357-376.

Vassenden, Kåre (1987) Folke- og boligtellingene 1960, 1970 og 1980. Rapport 87/2, Oslo - Kongsvinger, Central Bureau of Statistics of Norway.

Wærness, Kari (1987) “The Rationality of Caring”. In A.S. Saasson (ed.): Women and the State. London: Hutchinson.

Øyen, Ørjar (1964) "Krake søker make: En undersøkelse av homogami med hensyn til yrkesprestisje", Tidsskrift for samfunnsforskning, 5:179-88. 
Table A1: Cross tabulation of husband and wife's educational level by cohort. Percent. Men.

\begin{tabular}{|c|c|c|c|c|c|c|}
\hline \multirow[b]{2}{*}{ Cohorts } & \multicolumn{6}{|c|}{ Wife's education } \\
\hline & $\begin{array}{l}\text { Husband's } \\
\text { education }\end{array}$ & Compuls. & Second. I & Second. II & Col./uni.I & Col./uni.II \\
\hline \multirow[t]{8}{*}{ 1900-09 } & Compulsory & 67,4 & 3,0 & 1,0 & 0,3 & \\
\hline & Secondary I & 8,6 & 2,4 & 0,6 & 0,3 & \\
\hline & Secondary II & 5,3 & 2,1 & 0,8 & 0,3 & \\
\hline & Coll./univ. I & 1,6 & 0,6 & 0,4 & 0,3 & 0 \\
\hline & Coll./uni. II & 0,4 & 0,2 & 0,1 & 0,1 & 0,1 \\
\hline & Higher univ. & 1,0 & 1,4 & 1,0 & 0,4 & 0,3 \\
\hline & Total & 5381 & 618 & 264 & 111 & 31 \\
\hline & & 84,2 & 9,7 & 3,9 & 1,7 & 0,5 \\
\hline \multirow[t]{8}{*}{$1910-19$} & Compulsory & 64,9 & 3,8 & 1,4 & 0,3 & \\
\hline & Secondary I & 8,4 & 2,0 & 0,8 & 0,3 & 0,1 \\
\hline & Secondary II & 6,4 & 1,8 & 1,2 & 0,4 & 0,1 \\
\hline & Coll./univ. I & 1,6 & 0,7 & 0,7 & 0,4 & 0,1 \\
\hline & Coll./uni. II & 0,3 & 0,3 & 0,2 & 0,2 & 0,1 \\
\hline & Higher univ. & 0,6 & 0,8 & 1,0 & 0,5 & 0,5 \\
\hline & Total & 10569 & 1228 & 678 & 263 & 119 \\
\hline & & 82,2 & 9,6 & 5,3 & 2,0 & 0,9 \\
\hline \multirow[t]{8}{*}{$1920-29$} & Compulsory & 53,1 & 5,5 & 1,4 & 0,5 & 0,1 \\
\hline & Secondary I & 9,4 & 2,7 & 1,1 & 0,5 & 0,1 \\
\hline & Secondary II & 7,4 & 2,9 & 1,7 & 0,7 & 0,2 \\
\hline & Coll./univ. I & 2,4 & 1,8 & 1,1 & 0,8 & 0,3 \\
\hline & Coll./uni. II & 0,4 & 0,4 & 0,4 & 0,4 & 0,3 \\
\hline & Higher univ. & 0,8 & 1,0 & 1,1 & 0,9 & 0,7 \\
\hline & Total & 11349 & 2203 & 1043 & 579 & 275 \\
\hline & & 73,5 & 14,3 & 6,8 & 3,7 & 1,8 \\
\hline \multirow[t]{8}{*}{$1930-39$} & Compulsory & 40,6 & 7,7 & 1,5 & 0,8 & 0,2 \\
\hline & Secondary I & 9,7 & 4,2 & 1,3 & 0,7 & 0,2 \\
\hline & Secondary II & 8,8 & 4,1 & 2,0 & 1,0 & 0,2 \\
\hline & Coll./univ. I & 2,9 & 2,2 & 1,3 & 1,3 & 0,5 \\
\hline & Coll./uni. II & 0,5 & 0,7 & 0,5 & 0,8 & 0,6 \\
\hline & Higher univ. & 0,7 & 1,0 & 1,1 & 1,7 & 1,4 \\
\hline & Total & 8619 & 2695 & 1035 & 841 & 426 \\
\hline & & 63,3 & 19,8 & 7,6 & 6,2 & 3,1 \\
\hline
\end{tabular}


Demographic Research - Volume 8, Article 1

Table A1: $\quad$ Continued

\begin{tabular}{lllllll}
\hline & & \multicolumn{5}{c}{ Wife's education } \\
\cline { 5 - 6 } Cohorts & Husband's & Compuls. & Second. I & Second. II & Col./uni.I & Col./uni.II \\
\hline \multirow{1}{*}{$1940-49$} & Compulsory & 26,3 & 9,6 & 2,2 & 0,9 & 0,3 \\
& Secondary I & 9,3 & 5,5 & 1,8 & 1,1 & 0,2 \\
& Secondary II & 7,8 & 5,5 & 2,6 & 1,5 & 0,5 \\
& Coll./univ. I & 3,0 & 3,3 & 1,9 & 2,3 & 0,8 \\
& Coll./uni. II & 0,7 & 1,1 & 0,8 & 1,4 & 1,3 \\
& Higher univ. & 0,6 & 1,2 & 1,5 & 2,7 & 2,2 \\
& Total & 8972 & 4895 & 2031 & 1856 & 997 \\
& & 47,8 & 26,1 & 10,8 & 9,9 & 5,3 \\
$1950-59$ & Compulsory & 15,8 & 12,6 & 3,2 & 1,1 & 0,2 \\
& Secondary I & 6,6 & 10,0 & 3,6 & 1,4 & 0,3 \\
& Secondary II & 5,7 & 9,9 & 5,4 & 3,1 & 0,4 \\
& Coll./univ. I & 1,4 & 2,9 & 2,3 & 3,6 & 0,8 \\
& Coll./uni. II & 0,3 & 0,7 & 0,9 & 1,7 & 1,5 \\
& Higher univ. & 0,3 & 0,5 & 0,8 & 1,7 & 1,3 \\
& Total & 3434 & 4189 & 1868 & 1454 & 512 \\
& & 30,0 & 36,6 & 16,3 & 12,7 & 4,5 \\
\hline
\end{tabular}


Table A2: $\quad$ Cross tabulation of wife and husband's educational level by cohort. Percent. Women.

\begin{tabular}{|c|c|c|c|c|c|c|}
\hline \multirow[b]{2}{*}{ Cohorts } & \multicolumn{6}{|c|}{ Husband's education } \\
\hline & $\begin{array}{l}\text { Wife's } \\
\text { education }\end{array}$ & Compuls. & Second. I & Second. II & Col./uni.I & Col./uni.II \\
\hline \multirow[t]{8}{*}{$1900-09$} & Compulsory & 68,6 & 7,9 & 5,5 & 1,5 & 1,2 \\
\hline & Secondary I & 3,5 & 2,5 & 1,7 & 0,8 & 1,2 \\
\hline & Secondary II & 1,0 & 0,4 & 0,5 & 0,3 & 1,4 \\
\hline & Coll./univ. I & 0,4 & 0,2 & 0,2 & 0,2 & 0,6 \\
\hline & Coll./uni. II & & 0,1 & & & 0,1 \\
\hline & Higher univ. & & & & & 0,1 \\
\hline & Total & 3296 & 496 & 351 & 133 & 207 \\
\hline & & 73,5 & 11,1 & 7,8 & 3,0 & 4,6 \\
\hline \multirow[t]{8}{*}{$1910-19$} & Compulsory & 65,8 & 9,1 & 6,8 & 1,5 & 1,1 \\
\hline & Secondary I & 3,0 & 2,1 & 1,8 & 0,8 & 1,2 \\
\hline & Secondary II & 1,1 & 0,8 & 0,9 & 0,4 & 1,0 \\
\hline & Coll./univ. I & 0,3 & 0,2 & 0,3 & 0,3 & 0,6 \\
\hline & Coll./uni. II & & & & 0,1 & 0,2 \\
\hline & Higher univ. & & & 0,1 & & 0,3 \\
\hline & Total & 7699 & 1344 & 1084 & 335 & 480 \\
\hline & & 70,4 & 12,3 & 9,9 & 3,1 & 4,4 \\
\hline \multirow[t]{8}{*}{$1920-29$} & Compulsory & 56,7 & 9,3 & 7,4 & 2,4 & 1,1 \\
\hline & Secondary I & 4,6 & 2,5 & 2,6 & 1,3 & 1,4 \\
\hline & Secondary II & 1,4 & 1,1 & 1,5 & 0,9 & 1,6 \\
\hline & Coll./univ. I & 0,5 & 0,3 & 0,5 & 0,6 & 1,1 \\
\hline & Coll./uni. II & 0,1 & & 0,1 & 0,2 & 0,3 \\
\hline & Higher univ. & & & & & 0,3 \\
\hline & Total & 9405 & 1987 & 1799 & 799 & 879 \\
\hline & & 63,3 & 13,4 & 12,1 & 5,4 & 5,9 \\
\hline \multirow[t]{8}{*}{$1930-39$} & Compulsory & 43,8 & 9,5 & 8,8 & 2,9 & 1,4 \\
\hline & Secondary I & 6,8 & 3,7 & 3,7 & 1,9 & 1,8 \\
\hline & Secondary II & 1,8 & 1,3 & 1,7 & 1,2 & 1,8 \\
\hline & Coll./univ. I & 0,5 & 0,6 & 0,8 & 1,3 & 2,1 \\
\hline & Coll./uni. II & 0,2 & 0,1 & 0,3 & 0,3 & 1,0 \\
\hline & Higher univ. & & & & & 0,7 \\
\hline & Total & 7274 & 2094 & 2098 & 1052 & 1189 \\
\hline & & 53,1 & 15,3 & 15,3 & 7,7 & 8,7 \\
\hline
\end{tabular}


Table A2: $\quad$ Continued.

\begin{tabular}{lllllll}
\hline & & & \multicolumn{3}{l}{ Husband's education } & \\
Wife's & & & & \\
Cohorts & education & Compuls. & Second. I & Second. II & Col./uni.I & Col./uni.II \\
\hline $1940-49$ & Compulsory & 29,9 & 9,7 & 8,1 & 3,1 & 1,3 \\
& Secondary I & 8,5 & 5,3 & 5,0 & 2,9 & 2,3 \\
& Secondary II & 2,0 & 1,9 & 2,5 & 1,7 & 2,1 \\
& Coll./univ. I & 1,0 & 1,0 & 1,2 & 1,9 & 3,8 \\
& Coll./uni. II & 0,2 & 0,3 & 0,4 & 0,5 & 2,3 \\
& Higher univ. & & & 0,1 & 0,1 & 1,0 \\
& Total & 7712 & 3375 & 3212 & 1906 & 2385 \\
& & 41,5 & 18,2 & 17,3 & 10,3 & 12,8 \\
& Compulsory & 19,1 & 7,5 & 5,9 & 1,8 & 0,7 \\
& Secondary I & 12,4 & 8,9 & 8,1 & 3,0 & 1,6 \\
& Secondary II & 3,0 & 2,9 & 4,6 & 2,2 & 1,6 \\
& Coll./univ. I & 1,3 & 1,4 & 2,7 & 3,3 & 3,7 \\
& Coll./uni. II & 0,2 & 0,3 & 0,5 & 0,6 & 2,0 \\
& Higher univ. & & & 0,1 & 0,1 & 0,5 \\
& Total & 5456 & 3184 & 3324 & 1677 & 1529 \\
& & 36,0 & 21,0 & 21,9 & 11,1 & 10,1 \\
\hline
\end{tabular}


Demographic Research - Volume 8, Article 1 